\title{
Problem-Based Learning: Its Effects on Students' Ability in Writing Expository Essays
}

\begin{tabular}{l|l} 
Correspondence: & $\begin{array}{l}\text { Jumariati } \\
<\text { jumariati01@ulm.ac.id> } \\
\text { Rizky Amelia } \\
\text { <risky.amelia@ulm.ac.id> } \\
\text { Eka Puteri Elyani } \\
\text { <eka.elyani@ulm.ac.id> } \\
\text { Tofan Mahendra } \\
<1710117210038 @ m h . u l m . a c . i d>\end{array}$
\end{tabular}

\begin{abstract}
English Language and Education Study Program, Faculty of Teachers Training and Education, Universitas Lambung Mangkurat, Indonesia.

English Language and Education Study Program, Faculty of Teachers Training and Education, Universitas Lambung Mangkurat, Indonesia.

English Language and Education Study Program, Faculty of Teachers Training and Education, Universitas Lambung Mangkurat, Indonesia.

English Language and Education Study Program, Faculty of Teachers Training and Education, Universitas Lambung Mangkurat, Indonesia.
\end{abstract}

\section{Abstract}

Having the ability to think critically is prominent to aid students in dealing with academic life, filtering any information, and solving problems. This study investigates the effects of Problem-Based Learning (PBL) on students' ability in writing expository essays. It employed a quantitative approach with a quasi-experimental design by utilizing intact classes of advanced writing. The study utilized a writing test and a scoring rubric as the instruments to collect the data. The experimental group was taught by using PBL with group works whereas the control group was taught by using individual guided problem-solving. The findings on the t-test conveyed that the null hypothesis is rejected. Hence, there is a significant difference on the mean score of the students in the experimental group and those in the control group. Moreover, the analysis on each component of writing revealed that the implementation of PBL gives significant effect on the components of content and organization. Hence, small group discussion for problem-solving tasks is recommended to develop students' critical thinking skills, social skills, and writing skills particularly in writing expository essays of problem-solution.

Keywords: problem-based learning, learners' writing, expository essay

\section{Introduction}

Having the ability to think critically is prominent for students to aid them in dealing with the academic life, filtering any information, and solving problems. Hence, teachers can help build students' critical thinking skills by engaging them in problem-solving activities in the forms of presentations, debates, and essay writings all of which use factual and tangled issues as the basis they need to solve. Within Problem-Based Learning (henceforth PBL), students work in small groups to analyze a problem, list the possible solutions to the problem, and propose the best solution by explaining the reasons to back up their arguments (Jumariati \& Sulistyo, 2017; Ng Chin Leong, 2009). Hence, PBL builds students' critical thinking skills since they work collaboratively in exploring the issue, finding alternative solutions, building awareness on the consequences of each alternative solution, and proposing the most viable solution.

Research has been carried out to investigate the effects of PBL on EFL students' language skills including writing, speaking, and language components such as grammar (Chiou, 2019; Jumariati \& Sulistyo, 2017; Li, 2013; Ng Chin Leong, 2009). The research shows that PBL contributes to students' improvement on the areas investigated and helps them build collaborative skills. However, to the researchers' knowledge, investigation has not been made on the effect of PBL on students' ability in writing expository essays of problem-solution. Hence, there is a need to conduct this study to reveal potential roles of PBL in EFL writing particularly in writing expository essays of problemsolution.

Referring to the background of the study, the research question is formulated into:

Question: Do the students taught using Problem-Based Learning group works have better ability in writing expository essay than those taught using individual-guided problem-solving?

Consequently, the current study proposes the null hypotheses (Ho) and the alternative hypotheses (Ha) as follows.

Ho: There is no significant difference on the mean score of the students taught using Problem-Based Learning group works in writing expository essays and those taught using individual-guided problem-solving.

Ha: There is a significant difference on the mean score of the students taught using Problem-Based Learning group works in writing expository essays and those taught using individual-guided problem-solving.

\section{Literature Review}

PBL is a pedagogical approach that stimulates students' critical thinking skills as it requires them to find solutions to real-world problems (Hung, 2013). It is an approach that engages students in collaborative activities to recognize an issue, explore alternative solutions to the problem, and propose the best solution (Dole et al., 2015). Therefore, the students build understanding by analyzing and synthesizing the problem, evaluating the facts about the problem, and proposing the best solution to the problem. By doing so, they gradually develop their skills to think critically which also sharpen their higher order thinking skills when they try to analyze a problem from multiple perspectives and thus critical thinking skills and higher order thinking skills are interrelated (Yamin et al., 2021). 
PBL is rooted in the social constructivist theory that considers learners as social creatures who entailed to construct knowledge and interact with other people to develop their capacity (Dobao, 2012; Shehadeh, 2011). Students learn concepts collaboratively through communication with their classmates that gradually develop their social skills. Research has emphasized that learning through interactions can promote deep learning since it allows for experiencing the learning through questioning, expressing ideas, and listening to others' point of view (Pluta et al., 2013). In addition, within the constructivist approach, students are stimulated to think about how things work which triggers discovery learning (Aljohani, 2017). As research revealed, PBL stimulates intellectual capacity and collaborative learning as students learn to analyze a problem and find the solution collaboratively (Ng Chin Leong, 2009)

Studies show that collaboration in small-group discussion facilitates students' learning since it allows for better understanding on learning material through exchanging ideas. This activity also evolves students' critical thinking skills (Pollock et al., 2011) and increase students' engagement, learning, and performance (Jones, 2014). Therefore, it is essential that students are informed about the value of group work and the benefits of exchanging ideas to make them work collaboratively and evaluate the problem critically (Corden, 2001). In the context of EFL classrooms, more student-centered activities which engage students in collaborative learning is becoming more apparent (Hallinger \& $\mathrm{Lu}$, 2011; Othman \& Shah, 2013). The idea that underlies this concept is the need to facilitate students to build social skills and critical thinking skills. This is also true for the implementation of PBL in which the students work collaboratively to build social and critical thinking skills. Hence, the teachers should set clear rules on group work and show students how group work can bring benefits for them.

The procedure of PBL consists of problem presentation, problem analysis, research, and reporting (Burch, 2000) with distinctive roles of teacher and students. As students work in small groups, the teacher facilitates the students' learning by providing real-life tasks as the issue (Dole et al., 2015; Jonassen, 2011) to induce alternative solutions that allows for the development of argumentation skills. The teacher is also responsible for monitoring the small group discussion, guiding them to analyze the cause-effect of the problem, and guiding them to propose the best solution (Jonassen, 2011). To do this, the teacher provides leading questions about what, why, and how the issue occurs that gradually functions as a scaffolding to facilitate students in developing critical thinking skills (Hmelo-Silver \& Barrows, 2006; Jonassen, 2011).

Proposing arguments is essential as it develops students' skills in thinking critically. Hence, selecting the real-life and open-ended problem to be solved is necessary. A good problem is one which triggers students' interest, stimulates critical reasoning, promotes self-directed learning, enables application in students' real life, and promotes group work (Sockalingam \& Schmidt, 2011). In addition, using authentic materials in EFL classrooms is potential to help students develop language skills and critical thinking skills as they are engaged and motivated in the learning (Setyowati \& Sukmawan, 2019).

\section{Method}

\subsection{Population of the Study}

Given the nature that the current research was a quasi-experimental design, the population was the students enrolled in Advanced Writing Course at English Department of Undergraduate Program of the Faculty of Teachers Training and Education of Lambung Mangkurat University, Indonesia. The samples were students of two intact classes in which one class was randomly assigned as the experimental group taught by using PBL whereas the other class was randomly assigned as the control group taught by using guided problem-solving. By comparing the students' ability in writing expository essays in both groups, the potential effects of PBL on students' ability in writing can be revealed.

\subsection{Instrumentation}

This research utilized a writing test with validated writing prompt and scoring rubric. Prior to the test, a pilot study was carried out to students having similar characteristics with the samples of the current research. Additionally, this research employed inter-rater reliability in evaluating the students' writings by utilizing validated scoring rubric. The writing test required the subjects to write a five-paragraph expository essay on wetland environment issues by using problem-solution as the method of idea development. Table 1 depicts the scoring rubric utilized in the current research.

Table 1: Scoring Rubric of Expository Essay

\begin{tabular}{|c|c|c|c|c|}
\hline \multirow{2}{*}{$\begin{array}{c}\text { Components and } \\
\text { Weight }\end{array}$} & \multicolumn{4}{|c|}{ Criteria and Score } \\
\hline & Very Good (4) & Good (3) & Average (2) & Poor (1) \\
\hline Content 6 & $\begin{array}{l}\text { The problems and } \\
\text { solutions are discussed } \\
\text { clearly and supported } \\
\text { by strong reasons, } \\
\text { concrete examples, } \\
\text { and evidence. }\end{array}$ & $\begin{array}{l}\text { The problems and } \\
\text { solutions are discussed } \\
\text { clearly and supported } \\
\text { by concrete examples, } \\
\text { and evidence but the } \\
\text { quality of some } \\
\text { support is } \\
\text { questionable. }\end{array}$ & $\begin{array}{l}\text { The problem is } \\
\text { discussed slightly; } \\
\text { solutions are proposed } \\
\text { and supported by } \\
\text { evidence but the } \\
\text { quality is questionable. }\end{array}$ & $\begin{array}{l}\text { The problem is } \\
\text { discussed slightly; } \\
\text { solutions are given but } \\
\text { not supported by } \\
\text { strong and valid } \\
\text { evidence (only using } \\
\text { writer's opinions). }\end{array}$ \\
\hline Organization 6 & $\begin{array}{l}\text { The thesis statement is } \\
\text { introduced in the first } \\
\text { paragraph; the body } \\
\text { contains the problems } \\
\text { and solutions; the } \\
\text { concluding paragraph } \\
\text { restates the main topic } \\
\text { using different words } \\
\text { and sentence structure; } \\
\text { the transitions between } \\
\text { paragraphs are present } \\
\text { and effective. }\end{array}$ & $\begin{array}{l}\text { The thesis statement is } \\
\text { introduced in the first } \\
\text { paragraph; the body } \\
\text { contains the problems } \\
\text { and solutions but not } \\
\text { discussed in detailed; } \\
\text { the concluding } \\
\text { paragraph restates the } \\
\text { main topic; the } \\
\text { transitions are present } \\
\text { between most } \\
\text { paragraphs. }\end{array}$ & $\begin{array}{l}\text { The thesis statement } \\
\text { states the topic, not the } \\
\text { writer's purpose; the } \\
\text { body contains problem } \\
\text { and solutions but not } \\
\text { discussed in detailed; } \\
\text { the concluding } \\
\text { paragraph restates the } \\
\text { writer's idea; there are } \\
\text { few transitions } \\
\text { between paragraphs. }\end{array}$ & $\begin{array}{l}\text { There is no thesis } \\
\text { statement; the body } \\
\text { contains the problem } \\
\text { and solutions but not } \\
\text { discussed in detailed; } \\
\text { the concluding } \\
\text { paragraph repeats the } \\
\text { writer's ideas; } \\
\text { transitions are not } \\
\text { used. }\end{array}$ \\
\hline
\end{tabular}




\begin{tabular}{c|l|l|l|l}
\hline Vocabulary 5 & $\begin{array}{l}\text { The vocabulary used is } \\
\text { varied; the essay } \\
\text { exhibits effective word } \\
\text { choice. }\end{array}$ & $\begin{array}{l}\text { The vocabulary used is } \\
\text { varied but some (1-3) } \\
\text { word choice is } \\
\text { inappropriate. }\end{array}$ & $\begin{array}{l}\text { The vocabulary used is } \\
\text { not varied and some } \\
\text { (4-6) word choice is } \\
\text { inappropriate. }\end{array}$ & $\begin{array}{l}\text { The vocabulary is } \\
\text { limited; many of the } \\
\text { word choice (more } \\
\text { than 6) is } \\
\text { inappropriate. }\end{array}$ \\
\hline Grammar 5 & $\begin{array}{l}\text { The essay displays } \\
\text { correct and efficient } \\
\text { use of grammar. }\end{array}$ & $\begin{array}{l}\text { The essay displays } \\
\text { good use of grammar; } \\
\text { only 1-3 errors in } \\
\text { grammar. }\end{array}$ & $\begin{array}{l}\text { The essay displays 4-6 } \\
\text { errors of grammar. }\end{array}$ & $\begin{array}{l}\text { The essay displays } \\
\text { more than 6 errors of } \\
\text { grammar. }\end{array}$ \\
Mechanics 3 & $\begin{array}{l}\text { The essay uses correct } \\
\text { spelling and } \\
\text { punctuation. }\end{array}$ & $\begin{array}{l}\text { The essay displays } \\
\text { good use of spelling } \\
\text { and punctuation; only } \\
1-3 \text { total errors. }\end{array}$ & $\begin{array}{l}\text { The essay contains 4-6 } \\
\text { total errors of spelling } \\
\text { and punctuation. }\end{array}$ & $\begin{array}{l}\text { The essay contains } \\
\text { more than 6 total } \\
\text { errors of spelling and } \\
\text { punctuation. }\end{array}$ \\
\hline
\end{tabular}

\section{Data Analysis}

The current research aims at investigating the effects of PBL on EFL students' ability in writing expository essay. Hence, hypothesis testing should be conducted. Prior to hypothesis testing, the homogeneity and normality of the data needed to be measured. The homogeneity was measured by using One-Way ANOVA whereas the normality was measured by using Saphiro Wilk test. The findings established that the data were not from homogeneous groups since the significance value obtained was .019 which was less than the alpha value ( $\rho)$ that was .05 as presented in Table 2 .

Table 2: Result of Homogeneity Test

\begin{tabular}{l|c|c|c|c|c}
\hline & Sum of Squares & df & Mean Square & F & Sig. \\
\hline Between Groups & 232.93 & 1 & 232.93 & 3.892 & .055 \\
\hline Within Groups & 2453.77 & 42 & 59.85 & & \\
\hline Total & 2686.70 & 42 & & & \\
\hline
\end{tabular}

Meanwhile, the data were distributed normally in the experimental group but not in the control group. The test on the data in the experimental group found that the significance value obtained was .145, higher than the alpha value, whereas in the control group was .043 which was less than the alpha value. The data of normality testing are evinced in Table 3.

Table 3: Result of Normality Test

\begin{tabular}{l|l|c|c|c|c|c|c}
\hline \multirow{2}{*}{} & \multirow{2}{*}{ Group } & \multicolumn{3}{|c|}{ Kolmogorov-Smirnov } & \multicolumn{3}{c}{ Shapiro-Wilk } \\
\cline { 3 - 8 } & & Statistic & df & Sig. & Statistic & Df & Sig. \\
\hline \multirow{2}{*}{ Score } & Experiment & .174 & 25 & .05 & .94 & 25 & .15 \\
\cline { 2 - 8 } & Control & .215 & 18 & .03 & .893 & 18 & .04 \\
\hline
\end{tabular}

Since the data were not homogeneous and the distribution was not normal, the non-parametric test, Mann-Whitney test, was employed to test the hypothesis. The null hypothesis (Ho) is formulated as 'there is no significant difference on the mean score of the students taught using PBL in writing expository essays and those taught using guided problem-solving'. Meanwhile, the alternative hypothesis was formulated as 'there is a significant difference in the mean score of the students' taught using PBL in writing expository essays and those taught using guided problem-solving'. The result of non-parametric Mann-Whitney test is set forth in Table 4 for the descriptive statistic and Table 5 for the significant value obtained.

Table 4: Descriptive Statistics

\begin{tabular}{l|l|c|c|c|c}
\hline & Group & $\mathrm{N}$ & Mean & Standard Deviation & Standard Error Mean \\
\hline \multirow{2}{*}{ Score } & Experiment & 25 & 81.4 & 8.874 & 1.775 \\
\cline { 2 - 6 } & Control & 18 & 76.7 & 5.758 & 1.357 \\
\hline
\end{tabular}

The descriptive statistics of the scores in the test revealed that the mean score in the control group was 76.72 while the mean score in the experimental group was 81.44. The standard error mean for the experimental group was 1.78 whereas the control group was 1.34 . The result of hypothesis testing carried out by using Mann-Whitney test is given in Table 5.

Table 5: Result of Hypothesis Testing

\begin{tabular}{l|c}
\hline & Score \\
\hline Mann-Whitney U & 140 \\
\hline Wilcoxon W & 311 \\
\hline Z & -2.103 \\
\hline Asymp. Sig. (2-tailed) & 0.035 \\
\hline
\end{tabular}

As yielded in Table 4, the significance value obtained was .035 which was less than the alpha value .05 . Therefore, the null hypothesis is rejected. In other words, there was a significant difference on the mean score between the experimental group and the control group. To conclude, there is an effect of the implementation of PBL on the students' ability in writing expository essays in wetland environment issues.

The next analysis is on each component of writing measured namely content, organization, vocabulary, grammar, and mechanics to unfold which component is significantly affected by the implementation of PBL. Table 6 shows the summary of hypothesis testing on the component of content. 
Table 6: Result of Hypothesis Testing on the Content

\begin{tabular}{l|c}
\hline & Score \\
\hline Mann-Whitney U & 134 \\
\hline Wilcoxon W & 305 \\
\hline Z & -2.52 \\
\hline Asymp. Sig. (2-tailed) & 0.012 \\
\hline
\end{tabular}

As displayed in Table 6 , the significance value obtained was .012 which was less than the alpha value .05 . Therefore, there is a significant difference on the mean score of the content of the essay between the students taught using PBL and those taught using guided problemsolving. To conclude, PBL gives a significant effect on students' ability in writing the content of their essays. The next analysis is on the component of organization. The result is laid out in Table 7.

Table 7: Result of Hypothesis Testing on the Organization

\begin{tabular}{l|c}
\hline & Score \\
\hline Mann-Whitney U & 153 \\
\hline Wilcoxon W & 324 \\
\hline Z & -1.978 \\
\hline Asymp. Sig. (2-tailed) & 0.048 \\
\hline
\end{tabular}

Table 7 displays that the significance value obtained was .048. This value is less than the alpha value .05 which means that there is a significant difference on the mean score of the organization of students' essays between students taught using PBL and those taught using guided problem-solving. This concludes that PBL brings a significant effect on the students' ability in organizing their essays. The analysis on the component of vocabulary was also carried out. The result is shown in Table 8.

Table 8: Result of Hypothesis Testing on the Vocabulary

\begin{tabular}{l|c}
\hline & Score \\
\hline Mann-Whitney U & 179 \\
\hline Wilcoxon W & 504 \\
\hline Z & -1.395 \\
\hline Asymp. Sig. (2-tailed) & 0.163 \\
\hline
\end{tabular}

The analysis gave out a different result compared to previously mentioned results. As seen in Table 7, the significance value obtained was .163 which was higher than alpha value .05. This means that there is no significant difference in the mean scores of the vocabulary of students' essays between students taught using PBL and those taught using guided problem-solving. Hence, the implementation of PBL did not bring significant effect on students' vocabulary in expository essays. The analysis on the component of grammar is then carried out. The result is yielded in Table 9.

Table 9: Result of Hypothesis Testing on Grammar

\begin{tabular}{l|c}
\hline & Score \\
\hline Mann-Whitney U & 208 \\
\hline Wilcoxon W & 533 \\
\hline Z & -0.831 \\
\hline Asymp. Sig. (2-tailed) & 0.406 \\
\hline
\end{tabular}

Table 9 conveys that the significance value obtained was higher than the alpha value; it was .406. That is to say that there is no significant difference on the mean scores of the grammar of students' essays between students taught using PBL and those taught using guided problemsolving. It can be concluded that PBL did not give a significant effect on the students' ability in using grammar in their expository essays.

Finally, the analysis on the mechanics of the essay is also employed. Table 10 displays the result of the analysis showing that the significance value obtained was .069. This value is higher than the alpha value .05 . Thus, there is no significant difference in the mean scores of the mechanics of students' essays between students taught using PBL and those taught using guided problem-solving. This is to say that there is no significant effect on the implementation of PBL to students' ability in using mechanics in writing expository essays.

Table 10: Result of Hypothesis Testing on Mechanics

\begin{tabular}{l|c}
\hline & Score \\
\hline Mann-Whitney U & 161.5 \\
\hline Wilcoxon W & 332.5 \\
\hline Z & -1.817 \\
\hline Asymp. Sig. (2-tailed) & 0.069 \\
\hline
\end{tabular}

Based on the analysis on each component of writing, the implementation of PBL gives significant effect solely on the components of content and organization. The significance value obtained on these components arrayed that the difference on the mean scores of content and organization in the essays of students taught using PBL is significant. To conclude, the implementation of PBL has a significant effect on the students' ability in writing expository essays. Pertaining to the components of writing, PBL has a significant effect on the content and organization of students' expository essays in wetland environment issues.

The findings on the t-test revealed that the null hypothesis is rejected. Hence, there was a significant difference on the mean score of students taught using PBL and those taught using guided problem-solving. There are some possible reasons that underlie the findings. First, students in the experimental group experienced small group discussion that contributed to their ability in analyzing an issue. The group discussion helped them construct knowledge on the topic in which they analyzed a problem, reviewed literature, proposed possible solutions, and provided strong arguments. The activities of exchanging ideas, listening to others' point of view, analyzing the cause and effects, and 
providing arguments to support their ideas facilitated them in developing their ability to think critically. This confirmed that PBL engages students in collaboration to analyze an issue, find possible solutions, and propose the best solution (Dole et al., 2015). This means that students in PBL classroom work together to construct knowledge on the topic.

More specifically, as can be seen in the stages of PBL, students work in small groups to exchange ideas, listen to other's point of view, and settle any disagreement, if any, to come to a good conclusion. These activities build students' knowledge on the content and their social skills as well as critical thinking skills provided that the discussion is effective. A study disseminates that problem-solving activities carried out in group discussion resulted in effective group discussion which then increases students' interest and engagement in learning and thus improves their writings (Jones, 2014). This is to say that effective group discussion increases students' engagement which eventually facilitates their learning.

In a similar vein, small group discussion induces students' interest and engages them with the lesson (Pollock et al., 2011). Interestingly, the present study also revealed that small group discussion contributes to critical thinking and higher order thinking skills more than guided problem-solving class discussion. Even though class discussion also interests them in learning, the students assented that small group discussion is more stimulating and enriching compared to class discussion. This study also accentuates that small group discussion provides more equal participation among the members than class discussion. Cooperation among group members in the EFL writing classroom is essential as it can affect the result of group work (Hanifah et al., 2019). The study found that some students (18.3\%) did not participate in the group work which made the group work not effective. Meanwhile, another investigation on students' work in the PBL writing process showed that sharing tasks and responsibilities among group members contributed to students' writing improvement (Aliyu, 2020). Hence, equal participation among group members contributes to the effectiveness of the group work.

Students in the experimental group of the present study worked in small group discussion. In this way, they learned by listening to others' point of view, analyzing different ideas, expressing their own idea, resolving disagreement, and drawing conclusions. This finding confirms that small group discussion on problem-solving tasks stimulates students' critical thinking and higher order learning (Pollock et al., 2011). On the contrary, students in the control group did not experience small-group discussion as they did problem-solving tasks individually with limited guidance from the lecturer in a class discussion. This is to say that small-group discussion contributes to the development of students' learning in the experimental group of this study as they work with classmates to build knowledge on the topic. Hence, the students in the experimental group had better writing ability than the students in control group in terms of the content and organization of the essays.

The other possible justification for better writing performance in the experimental group is that small group discussion allows for sharing responsibilities and equal participation among group members. In this study, the students in the experimental group shared responsibilities by assigning each member of the groups to explore different things dealing with the cause and effect as well as to explore sources to support their arguments. This reflects the notion of constructionists wherein students help each other to build their comprehension on the lesson. The constructivist theory underlying the PBL classroom facilitates students in discovering new concepts by the scaffold from peers in the small groups (Aljohani, 2017; Pluta et al., 2013). This may lead to not only the developing of intellectual capacity but also social skills (Ng Chin Leong, 2009). The strength of small group discussion is apparent, therefore, it is essential that students are informed about the value of group work and benefits of exchanging ideas (Corden, 2001). In the current research, students in the experimental group were divided into small groups and assigned in breakout rooms of the Zoom meeting application to enable them to discuss intensively. The lecturer monitored each group to ensure that the discussion was focused and each member contributed in building knowledge on the topic. This is necessary as effective small group discussion is more engaging, interesting, and stimulating critical thinking compared to class discussion (Pollock et al., 2011).

The last possible reason is the role of the lecturer in facilitating the students in both the experimental and control group that aids the students in writing a problem solution essay. In this study, the lecturer provides the students with a list of questions about their ways to comprehend the issue that consisted of (1) what are the causes of the problems? (2) what are the effects? (3) what are the possible solutions to the problem? (4) what evidence do you have? (5) which solution do you think is the best? Why? These questions were provided for both groups to focus them on the work and check the progress of their problem-solving activity. The lecturer used this list to help the small group discussion in the experimental group and the students in the control group as well. However, the different nature of discussion in both groups apparently contributed to the effectiveness of the list use. The discussion in the control group was not as apparent as in the experimental group since only a few students participated in the discussion. This finding supports the statement that in a class discussion with teacher-fronted type, teachers usually dominate the talk (Alfares, 2017). On the contrary, the discussion in the experimental group was evident because the students felt comfortable to exchange ideas with their classmates in a smaller group than in a class discussion. This implies that the role of the lecturer in any classroom cannot be ignored particularly in this online mode of teaching and learning. Teachers should play the role to guide students and facilitate them in the learning (Jonassen, 2011).

As revealed in the findings, there is no significant difference on the mean scores in the vocabulary, grammar, and mechanics between the students in experimental group and those in the control group. Even though the result of $t$ test showed that the experimental group performed better than their counterparts in these linguistics components, the difference was proved to be not significant. Since these are the linguistics components that support students in writing, problem-solving tasks implemented in this study did not affect these components in both groups The possible reason for this finding is because the students are in advanced level which means they are knowledgeable about vocabulary, grammar, and mechanics they should use in their essays. Therefore, the implementation of PBL in the current research did not bring significant effect on these language components.

\section{Conclusion}

This study concludes that the implementation of PBL has a significant effect on the students' ability in writing expository essays. The study also vouchsafes that PBL contributes to students' ability in writing the content and organization of expository essays. Hence, small group discussion for problem-solving tasks like PBL classroom implemented in this study is recommended to develop students' critical thinking skills, social skills, and writing skills particularly in writing expository essays about problem-solution. However, it is essential to ensure that the small group discussion of PBL is effective. Therefore, teachers need to master the skills in managing small group works particularly when the class is carried out online so that the small group discussion runs effectively.

\section{Declaration of conflicting interest}

The author(s) declared no potential conflicts of interest with respect to the research, authorship, and/or publication of this article.

\section{Funding acknowledgement}

The authors thank Universitas Lambung Mangkurat (ULM), Lembaga Penelitian dan Pengabdian kepada Masyarakat of ULM, and Faculty of Teacher Training and Education of ULM for the support and fund to conduct and accomplish this study. 
Bio-notes

Dr. Jumariati is a senior lecturer at English Language Education Study Program of FKIP, Universitas Lambung Mangkurat. Her research interests are in the teaching of writing, language assessment, research in ELT, and ICT in teaching languages.

Rizky Amelia is a lecturer at English Language Education Study Program of FKIP, Universitas Lambung Mangkurat. Her research interests are in the teaching of writing, e-learning, and teacher professional development.

Eka Puteri Elyani is a lecturer at English Language Education Study Program of FKIP, Universitas Lambung Mangkurat. Her research interests are in the teaching of reading, e-learning, and teacher professional development.

Tofan Mahendra is a student at English Language Education Study Program of FKIP, Universitas Lambung Mangkurat. His research interest is in the writing skill.

\section{References}

Alfares, N. (2017). Benefits and Difficulties of learning in Group Work in EFL Classes in Saudi Arabia. English Language Teaching, 10(7), 247-256. https://doi.org/10.5539/elt.v10n7p247

Aliyu, M. M. (2020). Exploring the Nature of Undergarduates' Peer Collaboration in a PBL Writing Process. International Journal of Language Education, 4(1), 11-23. https://doi.org/10.26858/ijole.v4i2.8406

Aljohani, M. (2017). Principles of Constructivism in Foreign Language Teaching. Journal of Literature and Art Studies, 7, $97-107$. https://doi.org/10.17265/2159-5836/2017.01.013

Burch, K. (2000). A Primer on Problem-Based Learning for International Relation Courses. Internationla Studies Perspectives, 1, 3144. https://doi.org/10.1111/1528-3577.00003

Chiou, B. (2019). The Application of Problem-based Learning Approach in English Grammar Instruction: A Pilot Study. Journal of Language Teaching and Research, 10(3), 446-453. https://doi.org/10.17507/j1tr.1003.06

Corden, R. (2001). Group Discussion and the Importance of A Shared Perspective: Learning from Collaborative Research. Qualitative Research, 1(3), 347-367.

Dobao, A. F. (2012). Collaborative Writing Tasks in the L2 Classroom: Comparing Group, Pair, and Individual Work. Journal of Second Language Writing, 21, 40-58. https://doi.org/10.1016/j.jslw.2012.12.002

Dole, S., Bloom, L., \& Kowalske, K. (2015). Transforming Pedagogy: Changing Perspectives from teacher-Centered to LearnerCentered. Interdisciplinary Journal of Problem-Based Learning, 10(1). https://doi.org/10.7771/1541-5015.1538

Hallinger, P., \& Lu, J. (2011). Implementing Problem-Based Learning in Higher Education in Asia: Challenges, Strategies, and Effect. Journal of Higher Education Policy and Management, 33(3), 267-285. https://doi.org/10.1080/1360080x.2011.565000

Hanifah, Z., Suparno, \& Supriyadi, S. (2019). Implementing Collaborative Writing to Teach Writing for Non-English Major Students. International Journal of Language Teaching and Education, 3(2), 142-157. https://doi.org/10.22437/ijolte.v3i2.7907

Hmelo-Silver, C. E., \& Barrows, H. S. (2006). Goals and Strategies of a Problem-Based Learning Facilitator. Interdisciplinary Journal of Problem-Based Learning, 1(1), 21-39. https://doi.org/10.7771/1541-5015.1004

Hung, W. (2013). Problem-Based Learning: A Learning Environment for Enhancing Learning Transfer. New Directions for Adult and Continuing Education, 137, 27-38. https://doi.org/10.1002/ace.20042

Jonassen, D. (2011). Supporting Problem Solving in PBL. Interdisciplinary Journal of Problem-Based Learning, 5(2), $95-119$. https://doi.org/10.7771/1541-5015.1256

Jones, J. M. (2014). Discussion Group Effectiveness is Related to Critical Thinking through Interest and Engagement. Psychology Learning and Teaching, 13(1), 12-24. https://doi.org/10.2304/plat.2014.13.1.12

Jumariati, J., \& Sulistyo, G. H. (2017). Problem-Based Writing Instruction: Its Effects on Students' Skills in Argumentative Writing. Arab World English Journal, 8(2), 87-100. https://doi.org/10.24093/awej/vol8no2.6

Li, Y. (2013). Effects of Problem-Based English Writing Instruction on Thai Upper Secondary School Students' Critical Thinking Abilities and Argumentative Writing Skills. Online Journal of Education, 8(1), 242-255.

Ng Chin Leong, P. (2009). The Power of problem-based Learning in the EFL Classroom. Polyglossia, 16, 41-48.

Othman, N., \& Shah, M. I. A. (2013). Problem-Based Learning in English Language Classroom. English Language Teaching, 6(3), 125-134. https://doi.org/10.5539/elt.v6n3p125

Pluta, W. J., Richards, B. F., \& Mutnick, A. (2013). PBL and Beyond: Trends in Collaborative Learning. Teaching and Learning in Medicine: An International Journal, 25(1), 9-16. https://doi.org/10.1080/10401334.2013.842917

Pollock, P. H., Hamann, K., \& Wilson, B. M. (2011). Learning through Discussions: Comparing the Benefits of Small Group and Large-Class settings. Journal of Political Science Education, 7(1), 48-64. https://doi.org/10.1080/15512169.2011.539913

Setyowati, L., \& Sukmawan, S. (2019). Authentic Materials for Teaching Writing: A Critical Look. International Journal of Language Education, 3(2), 68-77. https://doi.org/10.26858/ijole.v3i2

Shehadeh, A. (2011). Effects and Student Perceptions of Collaborative Writing in L2. Journal of Second Language Writing, 20, 286305. https://doi.org/10.1016/j.jslw.2011.05.010

Sockalingam, N., \& Schmidt, H. G. (2011). Characteristics of problems for Problem-Based Learning: The Students' Perspectives Interdisciplinary Journal of Problem-Based Learning, 5(1). https://doi.org/10.7771/1541-5015.1135

Yamin, M., Saputra, A., \& Deswila, N. (2021). Enhancing Critical Thinking in Analyzing Short Story "The Lazy Jack" Viewed from Identity Theory. Indonesian Journal on Learning and Advanced Education, 3(1), 30-38. https://doi.org/10.23917/ijolae.v3i1.9948 